\title{
バス専用通行帯規制区間における 二輪車の通行方法に関する認識状況分析
}

\author{
稲垣 具志 1 - 小早川 悟 2 - 関根 太郎 3 - 中村 文彦 4 ・ \\ 福田 敦 5 ・清水 健造6 ・高田 邦道7 \\ 1正会員 日本大学助教 理工学部交通システム工学科（テ274-8501 千葉県船橋市習志野台7-24-1） \\ E-mail: inagaki.tomoyuki@nihon-u.ac.jp \\ 2正会員 日本大学教授 理工学部交通システム工学科（テ274-8501 千葉県船橋市習志野台7-24-1） \\ E-mail: kobaya@trpt.cst.nihon-u.ac.jp \\ 3 日本大学准教授 理工学部機械工学科（干101-8308 東京都千代田区神田駿河台1-8-14） \\ E-mail: sekine@mech.cst.nihon-u.ac.jp \\ 4正会員 横浜国立大学大学院教授 都市イノベーション研究院 \\ （干240-8501 神奈川県横浜市保土ヶ谷区常盤台79-5） \\ E-mail: f-naka@ynu.ac.jp \\ 5正会員 日本大学教授 理工学部交通システム工学科（†274-8501 千葉県船橋市習志野台7-24-1） \\ E-mail: fukuda.atsushi@nihon-u.ac.jp \\ 6株式会社アーバントラフィックエンジニアリング（†900-0032 沖縄県那覇市松山1-17-44） \\ E-mail: k.shimizu@utef.co.jp \\ 7フェロー会員 日本大学名誉教授（干274-8501 千葉県船橋市習志野台7-24-1） \\ E-mail: kunimic@solid.ocn.ne.jp
}

\begin{abstract}
全国各地において運用されているバス専用通行帯には，導入当初からの道路交通状況の変化により活用 方法の再検討が必要な事例も存在する。一方で, 世界的にも独特な二輪車混入率を有する我が国ではバス と二輪車で専用通行帯を共有する方策も見受けられ，混合交通の安全性と円滑性を確保する手法として検 討に值するものである。本稿では，専用通行帯規制区間における二輪車の通行にまつわる実態把握の一つ として，規制内容に関する二輪車ユーザの認識状況をアンケート調査により分析した。 その結果，バス専 用通行帯の原付や自転車による通行方法や, バス二輪車専用通行帯以外の通行帯の通行方法について極め て認識度が低いことが明らかとなり，標識・標識の提示，交通教育といった規制内容の周知手法について 課題が示された.
\end{abstract}

Key Words : bus lane, motorcycle, rule recognition of users, running position, awareness survey

\section{1. はじめに}

警察庁から各都道府県警に通達されている「交通規制

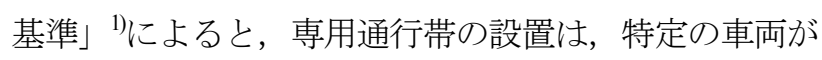
通行しなければならない専用通行带を指定し，かつ他の 車両が通行しなければならない車両通行帯として専用通 行帯以外の車両通行帯を指定することで, 交通の安全と 円滑を図ることを目的としている，そして対象となる道 路の一つとして，交通量が多く路線バス等輸送効率の高 い車両の正常な運行に著しく支障を及ぼすおそれのある 道路が挙げられており，全国各地においてバス専用通行
帯規制が多く運用されている.

バス専用通行帯の設置にあたっては，一般的に路線バ ス交通量が1方向1時間あたり50台以上で，交通混雑によ りバス運行に支障が生じる場合に導入が検討されるとい われている2). しかしながら，実際にはバス専用通行帯 の導入当初と比べてその存在意義が薄れているにもかか わらず設置が続けられている路線も少なくない，特に大 都市の都心部においては, 新規地下鉄路線の開通, 渋滞 対策や様々な交通需要マネジメント施策の展開を経て道 路交通状況が大きく変化しており, 道路空間の利用方策 を再検討する必要のある道路の存在を否定できない. 
このような中，国内にはバスの他に二輪車も専用通行 の対象に含んだ専用通行帯（以後「バス二輪車専用通行 帯」と呼ぶ.）の運用例もあり, 道路有効活用方策の選 択肢の一つとして検討に值するものである. 今後の専用 通行帯の効率的な運用方法について議論を展開するにあ たり，このような専用通行帯にまつわる規制の内容と二 輪車の通行方法が二輪車ユーザに正しく理解されていな ければ，実効性の高いバス二輪車専用通行帯の運用が見 込めない（規制の形骸化等）ばかりか，道路利用者に混 乱を与え混合交通の安全性と円滑性が阻害されるおそれ もある．そのため規制内容の検討の際には，専用通行帯 に関する二輪車ユーザの認識状況を把握し, 現行の標 識・標示の提示手法, 運転教育手法を評価することが重 要であるが，その実態については明らかになっていない のが現状である.

バス専用通行帯におけるバスと他車両との共存を取り 扱った既存研究としては, 自転車の車道左側通行の徹底 を目的としてバス専用通行帯の自転車走行を促進した社 会実験において, 挙動観察や意識調査を実施し走行ルー ルの遵守率や安全性等を評価したもの ${ }^{3)}$ ，東南アジアに おいて二輪車の混在がバス専用通行帯を走行するバスの 速度に与える影響を分析しバスサービス水準の維持には 二輪車の走行ルールの遵守率向上が必要不可久であるこ とを明らかにしたもの゙)，バス専用通行帯規制区間の車 両挙動を表現する交通シミュレーションを活用して導入 施策を事前評価し, 地域住民の交通行動变容一の促進効 果を検討したもの5)等が挙げられるが，世界的にも独特 な二輪車混合交通が形成されている我が国におけるバス 専用通行帯規制区間での二輪車の通行方法について, 道 路利用者の意識を分析した研究事例は見受けられない.

本稿では, 二輪車事故の特徵とバス専用通行帯規制区 間での二輪車の走行挙動特性について触れた上で，当該 規制区間の二輪車の通行方法について，二輪車ユーザの 認識状況をアンケート調査により把握し, 道路空間の有 效活用化を見据えた今後の専用通行帯規制のあり方につ いて基礎的な知見を得ることを目的とする．なお本稿に おいては，道路交通法の区分による排気量50 cc以下の原 動機付自転車を「原付」，排気量が50ccを超える二輪車 を「自動二輪車」とし，双方を合わせて「二輪車」（自 転車等の二輪の軽車両は含まない) と呼ぶこととする.

\section{2. 二輪車事故の特徵とバス専用通行帯規制区間 における交通実態}

国内の都市のうち，特に大都市中心部では二輪車の交 通安全問題を抱えている. 平成24年中に発生した人身事 故による死傷者のうち，二輪車乗車中の割合は全国で
11.9\% (0)であるのに対し, 東京都で $15.3 \%{ }^{7}$, 神奈川県で $22.6 \%{ }^{8}$ )，大阪府で $19.2 \%^{9}{ }^{9}$ と高くなっている. 平成22年に 発生した全国の事故類型別の人身事故件数に着目寸ると, 四輪車事故では，追突，出会い頭が多く発生している一 方, 二輪車事故では出会い頭の他に, 右折時, 左折時 （いずれも第1当事者の行動を表す）の占める割合が高 く, これらのうち二輪車が第2当事者である割合は, $87 \%$ (右折時)，95\%（左折時）と二輪車の相手が右左 折であるパターンが殆どであり, さらに二輪車が第2当 事者の場合の第1当事者による人的事故要因は，8割強が 「発見の遅れ」であることが指摘されている ${ }^{10)}$. このこ とから，二輪車が見落とされるような状況を極力生じさ せないことが二輪車事故抑制において重要な視点である といえるが，混雑しやすい都心の道路では渋滞車列間や 路肩でのすり抜けによって二輪車の見落としが誘発され, 右折直進事故や左折直進事故が発生しやすい環境にある と推察される.

一方，筆者らは道路空間の有效活用方策の一つとして, 専用通行帯の運用方法の見直しに着目し, バス専用通行 帯規制区間における二輪車の通行実態を分析している ${ }^{11)}$. その結果, バス専用通行帯の規制中に自動二輪車と原付 いずれにおいても通行帯境界付近の寸り抜けが多発して いることが確認できた．また，規制時間内と規制時間外 の走行挙動を比較すると, 自動二輪車の通行位置の特性 が大きく異なっており, 規制の有無が二輪車ユーザの通 行位置選択に与える影響が大きいことがわかった．さら に, 自動二輪車の速度は寸り抜け時に高くなる傾向があ り, 近接の四輪車との間に大きな速度差が生じやすいこ とが判明した. 以上のような分析結果から, 原付に加え て自動二輪車にもバス専用通行帯の通行権を与えること で四輪車と異なる通行帯に誘導すると, 高速度の寸り抜 けのような危険度の高い状況が抑制され，道路全体の安 全性や円滑性が向上寸る可能性があるとの結論を得た. しかし，国内で導入されているバス二輪車専用通行帯に おいて, 実際に二輪車ユーザが規制の内容をどの程度理 解し, どのような認識で走行しているのかは把握されて おらず，このまま専用通行帯の運用方法の見直しを検討 することは，道路利用者の混乱や規制の形骸化を招くお それも否定できない.したがって本稿では, 二輪車ユー ザーに対してバス専用通行帯やバス二輪車専用通行帯の 通行経験や通行方法に関する認識状況を把握することで, 今後の専用通行帯の運用方法について検討を試みる.

\section{3. 調査概要}

バス専用通行帯における二輪車の通行方法に関する二 輪車ユーザの認識状況を把握するためアンケート調査を 
表-1 アンケート調査の概要

\begin{tabular}{|c|c|c|}
\hline 調査対象 & $\begin{array}{l}\text { 東京都および神奈川県横浜市, } \\
\text { 川崎市に居住する二輪車ユーザ } \\
\text { 412名 }\end{array}$ & $\begin{array}{l}\text { 横浜国立大学学生の二輪車ユーザ } \\
25 \text { 名 }\end{array}$ \\
\hline 調査方法 & ウェブアンケート & 調査用紙によるアンケ \\
\hline 実施期間 & 2012年 12月 26日(水)～27日 日) & 2013年1月9日(水)～11日(金) \\
\hline 質問項目 & \multicolumn{2}{|c|}{$\begin{array}{l}3 \text { 車線道路での車線選択と通行位置 } \\
\text { ・バス専用通行帯規制区間の走行経験 } \\
\text { ・バス専用通行帯の通行経験 } \\
\text { • 通行ルールに関する認識状況 } \\
\text { • 個人属性 (年齢, 性別, 免許保有状況, 二輪車の使用目的, 通算 } \\
\text { 走行距離など) }\end{array}$} \\
\hline
\end{tabular}

実施した．調査の概要を表-1に示す．調查対象は，バス 専用通行帯の二輪車通行が禁止されている東京都と，規 制対象路線のほぼ全延長においてバス二輪車専用通行帯 を導入している神奈川県の両都県に居住する二輪車ユー ザとした．まず，ウェブアンケートにより東京都と神奈 川県在住の二輪車ユーザを抽出し回答を得た.さらに, 若年層の回答を補完するために神奈川県在住の横浜国立 大学の学生を対象にウェブアンケートと同内容の紙媒体 によるアンケート調査を実施した，回答者の個人属性は 男性が約7割とやや多く，年齢層（図-1）では30～50代 が大部分を占め，その中で年齢構成に大きな偏りは見ら れない。二輪車の使用目的は通勤・通学が約3割, 買い 物が約5割を占めており, 回答者の多くが日常的な二輪 車ユーザである．アンケートでは，まず片側3車線道路 走行時の通行位置の選択特性を把握するために，図-2の 写真を示して当該道路を走行すると想定した場合の通行 位置を尋刘た，続いて図-3，図-4の規制標識の写真を示 して，バス専用通行帯規制区間の走行経験，バス専用通 行帯・バス二輪車専用通行帯の通行経験について回答を 得た. また, 両専用通行帯における通行方法について正 しく認識しているかを確認するための質問を設定した.

\section{4. 通行位置の選択傾向とバス専用通行帯の通行経験}

\section{（1）3車線道路における通行位置選択}

図-2のように例示した3車線道路における回答者の通 行位置選択状況を，走行を想定寸る車種別に示したもの が図-5である，通行位置の回答にあたり，第一通行帯か らA，B，Cと記号を振り, 各通行帯を左側, 中央, 右側 の3つに区切って9通りのパターンを設定し，これに「分 からない」を合わせた計10個の選択肢を設けている.

「分からない」とは該当する車種の運転経験がないため 分からないという意味であり，この場合通行位置を想像 で回答しており選択傾向の実態が把握できないおそれが あるため図-5では対象外としている。同様の理由により， 該当する車種の通算走行距離が $0 \mathrm{~km}$ と答えた回答者につ いても除外している.

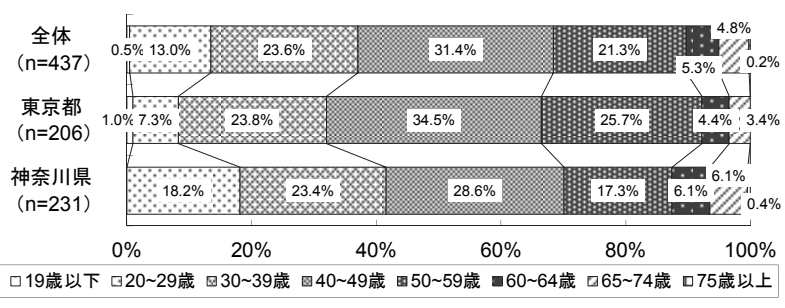

図-1 回答者の居住地域別年齢構成

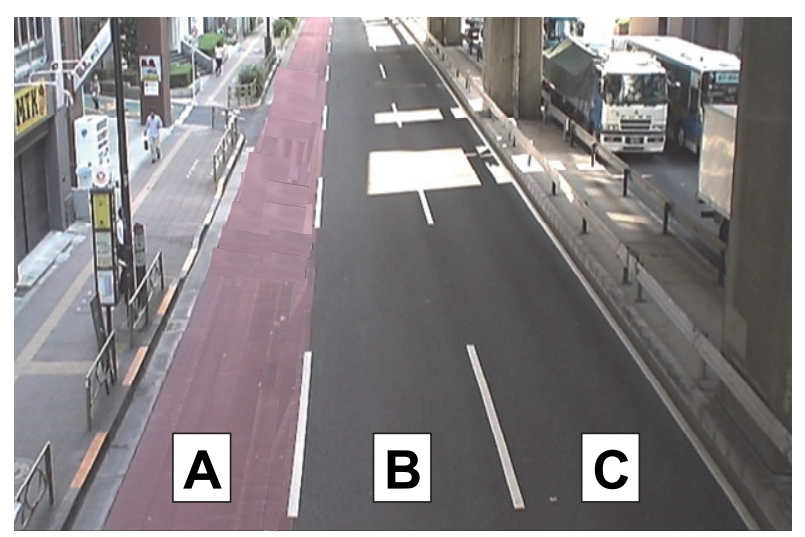

図-2 片側3車線道路の事例写真
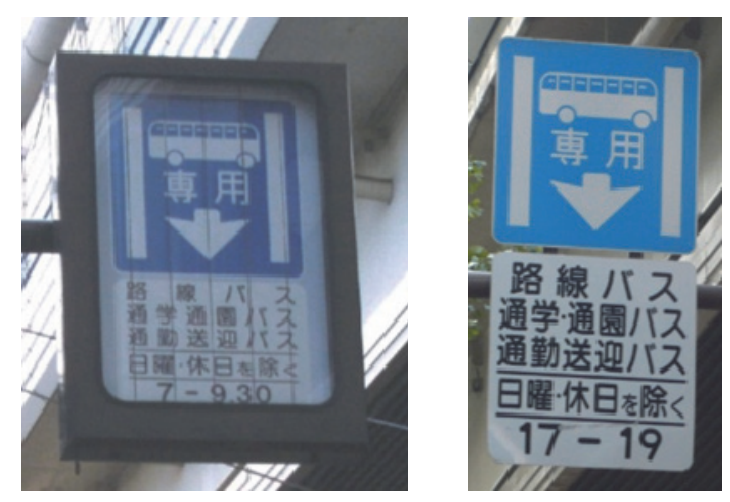

図-3 バス専用通行帯の規制標識

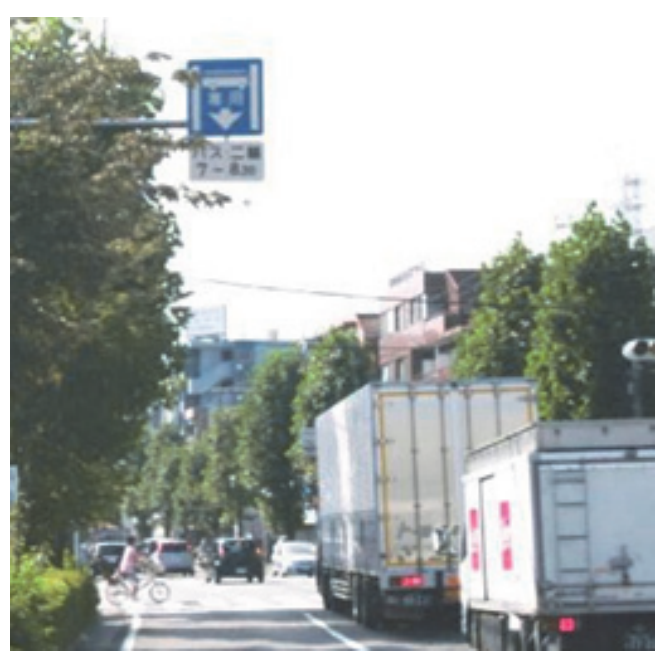

図-4 バス二輪車専用通行帯の規制標識 
$\chi^{2}$ 值による独立性検定の結果，車種間に水準 $1 \%$ で有 意差が認められた．原付では，回答者全体の約 8 割が第 一通行帯を選択しており，その中でも左側の選択率が顕 著に高く, 道路交通法のいわゆるキープレフトの影響が 現れているといえる. 第二通行帯は $15 \%$ 程度, 第三通行 帯は2\%程度選択されている. 自動二輪車では，第一通 行帯, 第二通行帯, 第三通行帯の各選択率が, それぞれ $38.1 \% ， 57.7 \% ， 4.2 \%$ と第二通行帯が最も高く, 原付と比 べて第一通行帯の割合が大きく減少している．第一・第 二通行帯内の詳細な通行位置については, 原付と同様に 右側の割合が非常に低く，左側や中央の選択傾向が強い しかし，第一通行帯では左側と中央がほぼ同程度の割合 で，第二通行帯では中央が選ばれやすくなっておりこの 点においては原付と異なる. 残差分析においては，A左 側，B左側，B中央，B右側，C中央に有意差が認められ， 自動二輪車は原付と比べて第一通行帯左側の通行割合が 低くなる分, 第二通行帯や第三通行帯中央が多くなるも のと考えられる.

\section{（2）バス専用通行帯規制中の道路区間の走行経験}

バス専用通行帯の規制標識として図-3の写真を示し, バス専用通行帯規制中の道路区間の走行経験（バス専用 通行帯を通行したか否かは関係なし）について回答して もらった内容を回答者居住地域別に示したものが図-6で ある．凡例内「東京都内」「神奈川県内」とは，それぞ れの地域内において走行したことがあるという意味であ る. 全体のうち約半数がバス専用通行帯規制中の道路区 間の通行経験があり，東京都内の方が神奈川県内より多 くなっている. 回答者居住地域別では各地域内の区間の 方で割合が高い中，神奈川県在住者が東京都内区間を走 行した割合は「両方」を合わせて $17.3 \%$ ，東京都在住 者が神奈川県内区間を走行した割合 $(5.8 \%)$ より高い. ここで, 神奈川県では規制路線のほぼ全区間においてバ ス二輪車専用通行帯であるが，質問文内で提示したバス 専用通行帯の写真（図-3）を同様の規制内容として捉え ている状況が窺える. そのため, このようなユーザはバ 又専用通行帯を自動二輪車で通行し違反するか, バス二 輪車専用通行帯を自動二輪車で通行できないと考えてい ることが懸念される.

\section{（3）バス専用通行帯の通行経験}

図-7はバス専用通行帯の二輪車での通行経験状況を居 住地域別にみたものである.「原付」「自動二輪車」と は各車種で通行した経験があることを表す，全体の約半 数がバス専用通行帯の通行経験があり, その中で原付の 割合が最も高い. 東京都在住者のうち自動二輪車で通行 経験のある割合は「自動二輪車」と「両方」を合わせて 25.2\%であるが，図-6より東京都在住の規制中区間の走

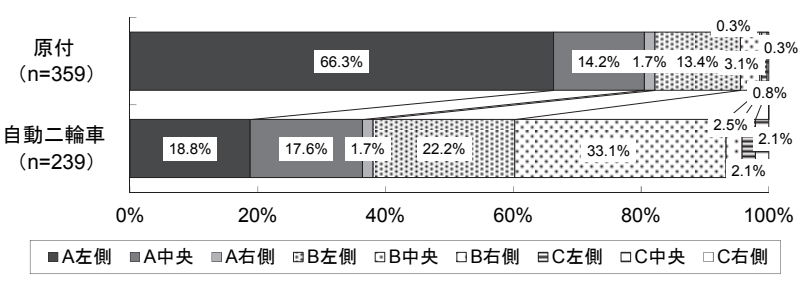

※回答不明·「分からない・走行牛口0km孝除く

図-5 3車線道路における通行位置選択

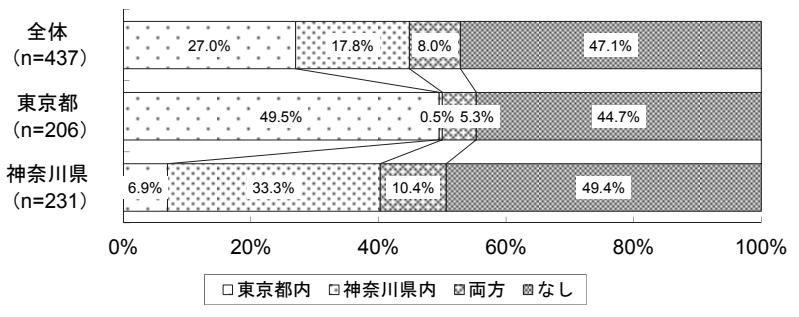

図-6 居住地域別バス専用通行帯規制中の道路区間の走行経験

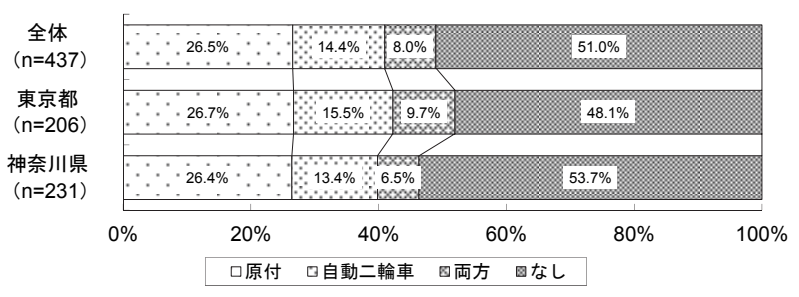

図-7 バス専用通行帯の通行経験

行経験者が約 $50 \%$ でそのほとんどが東京都内の区間のみ であることから，規制区間を走行したことのあるユーザ のうち約半数がバス専用通行帯の通行違反経験があるこ ととなる．神奈川県在住者については，図-7において自 動二輪車で通行経験のある割合が東京都在住者と同程度 であるが，図-6で神奈川県在住の規制区間走行経験者の 多くが神奈川県内の規制区間を走行していることより, これらのユーザが調査票で示したバス専用通行帯規制標 識の写真をバス二輪車専用通行帯の規制標識と混同して いる可能性が高い.

\section{（4）バス二輪車専用通行帯の通行経験}

バス二輪車専用通行帯の規制標識として図-4の写真を 示し, バス二輪車専用通行帯の通行経験について得た回 答を居住地域別にみたものが図-8である．東京都内には バス二輪車専用通行帯が存在しないにもかかわらず，通 行したと答えた東京都在住者が約4割を占めており, 標 識によって示された規制内容を誤って認識しているユー ザが多く存在する. また神奈川県内在住者の回答状況が 図-7と大きく変わらないことから，バス二輪車通行帯が あくまでバス専用通行帯の一形態と認識されていること が分かる. 
次に, バス二輪車専用通行帯の規制中は自動二輪車 には当該通行帯の通行義務が生じるため, 当該通行帯以 外の通行帯を走行してはならない（原付にはこの義務は なく第一通行帯通行のキープレフトの原則が適用され る）。ここで，バス二輪車専用通行帯規制中の区間での 当該通行帯以外の通行経験状況を示したものが図-9であ る. 神奈川県在住者に着目寸ると, 規制中の道路区間を 走行した経験のある回答者のうちの多くが，二輪車で専 用通行帯以外を通行している. 東京都在住者で通行した ことがあると答えている回答者については，大半がバス 二輪車専用通行帯ではなくバス専用通行帯について当該 通行帯以外の通行帯の通行経験を回答しているものと推 察されるが，原付が「両方」を含めて約3割を占めてお りキープレフトが遵守されていない可能性がある.

\section{5. 二輪車の通行方法に関する認識状況}

アンケート調査では, バス専用通行帯, バス二輪車専 用通行帯，バス二輪車専用通行帯以外の通行帯の通行方 法に関する二輪車ユーザの認識状況を把握するため, 回 答者に「○○ (各種通行帯) を $\times \times$ (原付, 自動二輪車 等の車種）で通行することができる」という文章を提示 し，正誤を判断させる形式で回答を得た．以下では各種 通行帯について認識状況を考察する. なお, 内容を正し く認識できている回答者の割合を, 以後「認識率」と呼 ぶこととする.

\section{（1）バス専用通行帯の通行方法に関する認識}

バス専用通行帯は自転車と原付は通行可であるが自動 二輪車は通行できない，このことについて車種別に回答 者の認識状況を示したものが図-10である．凡例中，

「分からない」とは，通行方法について分からないと答 えた回答者のことである.また原付と自動二輪車につい ては該当する車種の通算走行距離が $0 \mathrm{~km}$ のサン゚ルは除 外している（以後，同様）。攵值による独立性検定の結 果，車種間に水準 $1 \%$ で有意差が認められた。自転車の 通行方法の認識率は $40.5 \%$ で，バス専用通行帯を自転車 で走行できないと考えている回答者が約半数である. 原 付においては最も認識率が低く約28.7\%で（残差分析に おいて $1 \%$ 有意），原付がバス専用通行帯を通行可であ ることが多くのユーザに浸透していない状況がわかる.

自動二輪車については $80.0 \%$ 落行できないと答えてお り約 $10 \%$ が誤認識している. いずれも居住地域による傾 向の差は認められなかった。 また「分からない」の割合 は自転車で最も高く, 運転免許所有者であってもバス専 用通行帯における自転車の扱いを理解できていない場合 がある.

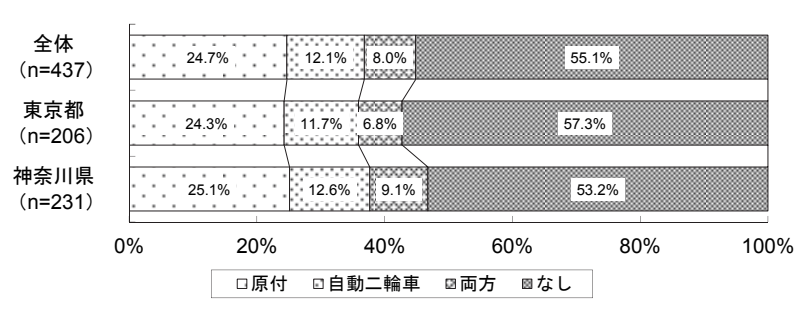

図-8 バス二輪車専用通行帯の通行経験

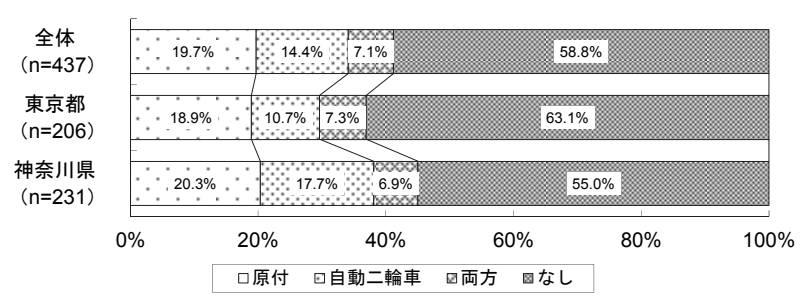

図-9 バス二輪車専用通行帯以外の通行帯の通行経験

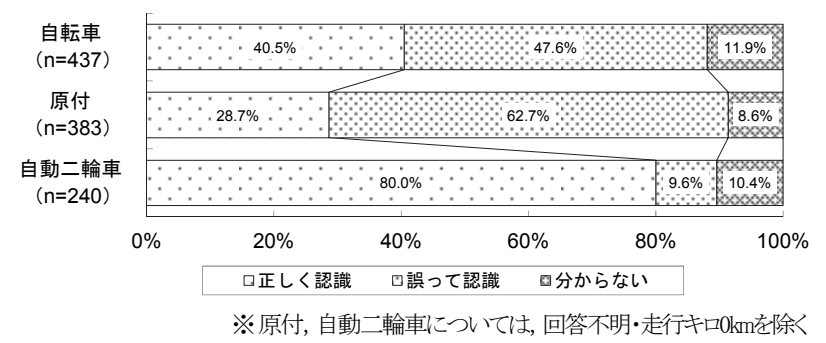

図-10 バス専用通行帯の通行方法に関する認識

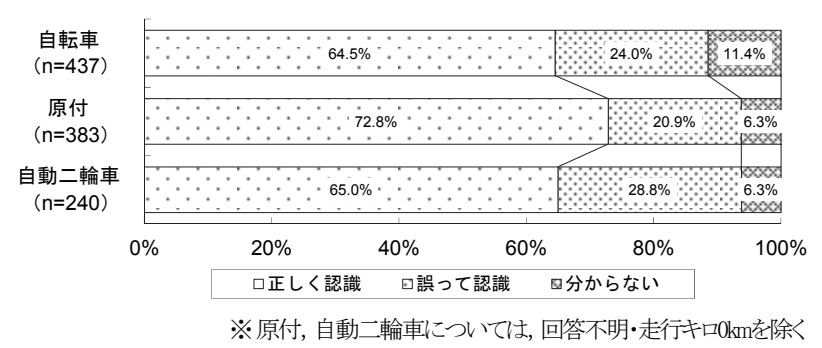

図-11 バス二輪車専用通行帯の通行方法に関する認識

\section{（2）バス二輪車専用通行帯の通行方法に関する認識}

バス二輪車専用通行帯は自転車，原付，自動二輪車と もに通行可能である.このことについて車種別に回答者 の認識状況を示したものが図-11である， $\chi^{2}$ 值による独 立性検定の結果，車種間に水準 $1 \%$ で有意差が認められ た. 自転車, 原付と比べて自動二輪車で誤認識の割合が 高く（残差分析において $5 \%$ 有意），28.8\%が補助標識で 二輪車も専用通行の対象であることを示しても認識がで きず, 結果として専用通行帯以外の通行帯を通行するこ ととなり, 前章における通行経験の結果を裏付けるもの である．地域比較では東京都の方が誤認識の割合が高く, バス二輪車専用通行帯が未導入であることが影響してい るものと考えられる．また「分からない」と回答した割 合はバス専用通行帯の場合と同様自転車で最も高く（残 差分析において $1 \%$ 有意）, 補助標識に「二輪」表示が 付されても傾向に変化はない. 
（3）バス二輪車専用通行帯以外の通行帯の通行方法に 関する認識

バス二輪車専用通行帯規制中において，当該通行帯以 外の通行帯は, 原付, 自動二輪車ともに通行できない. このことについて車種別に回答者の認識状況を示したも のが図-12である， $\chi^{2}$ 值による独立性検定の結果，車種 間に水準 $1 \%$ で有意差が認められた。いずれの車種にお いても多くの回答者がバス二輪車専用通行帯以外の通行 帯を通行できると䛊って認識しており，キープレフトの 原則のある原付と比べて自動二輪車では72.1\%とその割 合が顕著に高い（残差分析において $1 \%$ 有意）。以上の ことより, バス専用通行帯，バス二輪車専用通行帯に係 る二輪車, 自転車の通行方法についてユーザに十分認識 されているとは言い難く, 新たな標識, 標示の提示方法 の開発，教育場面における規制周知方法の改善によって, 道路利用者の認識との乘離を是正する必要があるといえ る.

\section{6. まとめと今後の課題}

本稿では, 都市中心部の二輪車交通量が多い道路区間 における空間有効活用方策として, バス専用通行帯のバ スと二輪車の共有や専用通行帯そのもののあり方に関す る提言を目指し，そのための基本的な現状把握の一つと してバス専用通行帯の規制内容に関する二輪車ユーザの 認識状況についてアンケート調査により分析した.

その結果，バス専用通行帯を自動二輪車で通行できな いことや，バス二輪車専用通行帯を二輪車で通行できる ことは概ね正しく認識されているものの, バス専用通行 帯を自転車・原付で通行可能なことが認識されていない ことや, 特にバス二輪車専用通行帯以外の通行帯を二輪 車が通行できないことについて極めて認識度が低いこと が明らかとなった，そのため，バスの運行本数や二輪車 混合交通の安全性・円滑性等といった，バス専用通行帯 規制区間の空間利用状況を鑑み，道路空間の有効利用の 観点からバス専用通行帯をバス二輪車専用通行帯へ移行 させることが妥当であると判断されたとしても，規制内 容に対する二輪車ユーザの正しい理解と同意を得るため の簡潔で齟跴のない内容の周知手法や効果的な教育手法 を考案，実践することが必要である.

今後は，意識調查のみならずバス二輪車専用通行帯の 実施区間における実交通流の観測に基づいて，バス専用 通行帯での交通流実態と比較しながら走行挙動を評価す ることや, 自転車やパーソナルモビリティといった中速 モードとの共存性を含めた議論を展開することが課題で ある。

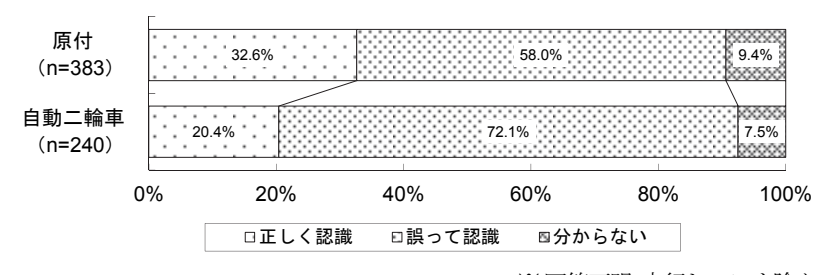

図-12 バス二輪車専用通行帯以外の通行帯の通行方法に 関する認識

謝辞 : 本研究は, 公益社団法人日本交通政策研究会の自 主研究プロジェクト「二輪車のバス専用通行帯通行に関 する研究」の一環として実施されたものである.ここに 記して研究会ならびに委員各位一感謝申し上げる次第で ある.

\section{参考文献}

1）警察庁：「交通規制基準」の改正について，警察庁 丙規発第 3 号・警察庁丙交企発第 10 号, 2011.

2) 交通工学研究会: 交通工学ハンドブック, 技報堂, 1973.

3) 片岸将広, 岡田茂彦, 高山純一, 石川俊之, 埒正 浩：バスレーンを活用した「自転車走行指導帯」の 設置による交通安全対策の効果と課題, 土木計画学 研究・論文集, Vol. 25, No. 3, pp. 597-606, 2008.

4) Tranhuu, M., Montgomery, F. and Timms, P. : Modeling bus lane priorities in a motorcycle environment using SATURN, Transportation Research Record, No. 2038, pp. 167-174, 2007.

5) 坂本邦宏, 福本大輔, 久保田尚, 福島健二: パネル データを用いた交通シミュレーションと社会実験の 評価一静岡市交通実証実験を巡って一, 土木計画学 研究・論文集, Vol. 21, No. 3, pp. 737-744, 2004.

6) 警察庁交通局 : 平成 24 年中の交通事故の発生状況, 2013.

7) 警視庁：二輪車の交通事故発生状況～平成 24 年中， http://www.keishicho.metro.tokyo.jp/toukei/jiko/jiko4.htm (2013.8.2 確認).

8) 神奈川県警察本部交通部交通総務課：かながわの交 通事故平成 24 年統計, 2013.

9) 大阪府交通安全協会: 大阪の交通白書平成 24 年版, 2013.

10) 財団法人交通事故総合分析センター：イタルダイン フォメーション, No. 91, 2011.

11) 稲垣具志, 関根太郎, 小早川悟, 清水健造, 高田邦 道 : バス専用通行帯規制区間における二輪車の走行 実態の特徴分析, 自動車技術会学術講演会前刷集, No. 151-13, pp. 5-10, 2013.

(2014. 2. 28 受付) 


\title{
A STUDY ON RECOGNITION OF RULES FOR MOTORCYCLES ON THE ROADS WITH BUS LANE
}

\author{
Tomoyuki INAGAKI, Satoru KOBAYAKAWA, Taro SEKINE, Fumihiko \\ NAKAMURA, Atushi FUKUDA, Kenzo SHIMIZU and Kunimichi TAKADA
}

As for some of bus lanes, we should have to review their appropriate usage because of the change of the road and traffic situation since these lanes were introduced. Motorcycle mixed traffic in Japan has a unique motorcycle mixing state in the world and there are examples of the traffic control method as to share the exclusive lane between buses and motorcycles. This method is worthy of consideration as a way to realize safe and smooth motorcycle mixed traffic. In this paper the authors analyzed the rule recognition of motorcycle users through the awareness survey as an understanding the actual situation concerning passage of a motorcycle on a road section including a bus lane. Consequently it was found that motorcycle users have a very weak recognition of the rule for a motorbicycle and a bicycle in a bus lane and that for a motorcycle in lanes outside a bus lane, therefore many challenges still exist, both in informing road users of the rule in the bus lane and in whole concept of traffic regulation about a bus lane. 